\title{
ANALISIS KRITIS KONSEP KEPEMILIKAN HARTA DALAM ISLAM
}

\section{Fitri Utami ${ }^{1}$, Dini Maulana Lestari'2, Khaerusoalikhin ${ }^{3}$}

1 Universitas Islam Negeri (UIN) Sunan Kalijaga Yogyakarta e-mail: fitriutami222@gmail.com

2 Universitas Islam Negeri (UIN) Sunan Kalijaga Yogyakarta e-mail: maulanalestari87@gmail.com

3 Universitas Islam Negeri (UIN) Sunan Kalijaga Yogyakarta e-mail: solikhink66@gmail.com

\begin{tabular}{|l|l|l|}
\hline Submit: 03-08-2020 & $\begin{array}{l}\text { Direvisi: 10-08-2020, } \\
\text { 19-11-202 }\end{array}$ & Dipublish: 18-12-2020 \\
\hline
\end{tabular}

Abstract: Wealth or property is the esential thing which has a thighten relationship throug human life. Islam has already well organized regarding to wealth or property ownership. One of Islamic property ownership concepts is Ihrazul Mubahat which means free property ownership. However, is ibrazul mubahat concept appropriate if it is implemented in Indonesia? While as known as Indonesia has two resources of law, those are positive law and sharia law. The purpose of this article is to discuss deeply regarding to implementasion of ihrazul mubahah concept in Indonesia, and this is kind of descriptive qualitative method research throgh library research approach. The result of this research revealed that in Islamic property and ownership specifically ibrazul mubahat concept needs such a regulation in the term of Islamic law regarding to enrole of ihrazul mubahah concept properly, thus it can be adapted into Indonesia's law system.

Kata kunci: Harta, Kepemilikan, Islam

\section{PENDAHULUAN}

$\mathcal{H}$ arta merupakan suatu hal yang memiliki nilai esensial yang tinggi dalam kehidupan manusia. Harta digunakan sebagai salah satu komponen yang diberdayakan guna untuk memenuhi kebutuhan hajat hidup manusia (Suhendi, 2013). Dengan demikian, harta dapat dmaknai sebagai segala zat yang berharga, bersifat materi dan memiliki daya guna yang dapat di manfaatkan oleh manusia.

Menurut Wabah az-Zuhaili, harta secara bahasa harta adalah al-māl yang memiliki arti kecondongan, kecenderungan, serta kemiringan. Harta yang dimaksud dalam kalimat tersebut merupakan segala sesuatu yang diperoleh atau yang dibutuhkan oleh manusia seperti emas, perak, atau binatang, yang terkategori sebagai objek yang tampak. Tidak hanya dalam objek yang tampak, namun dalam bentuk yang abstrak yang dapat diambil manfaatnya seperti kendaraan, pakaian dan tempat tinggal, sesuatu yang tidak bias dikuasai oleh manusai tidak bias dikatakan sebagai sebuah harta seperti burung yang berada diangkasa. (az-Zuhaily, 2004)

Islam mempunyai cara pandang tersendiri mengenai konsep harta dan kepemilikannya. Dalam Islam, jelas disebutkan bahwasanya segala sesuatu yang berharga yang ada di dunia ini 
hanyalah milik Allah semata, dimana manusia hanya berperan sebagai khalifah yang mengemban amanah sebagai khalifah di bumi yang memiliki hak untuk memanfaatkan atau meberdayagunakannya sehingga dapat dimanfaatkan oleh manusia agar dipergunakan dengan sebaik-baiknya dengan misi untuk kesejahteraan bersama. Hal ini sesai dengan firman Allah SWT dalam surat alBaqarah ayat 30:

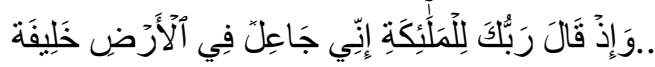

"Ingatlah ketika Tuhanmu berfirman kepada para Malaikat: Sesungouhnya Aku hendak menjadikan seorang khalifah di muka bumi" (QS. al-Baqarah [2]: 30).

Dalam penggunaannya, harta dapat dijadikan sebagai objek kepemilikan dan juga sebagai objek bisnis. Harta sebagai objek kepemilikan dapat dimaknai sebagai pendagayagunaan atas asas kebermanfaatan dari harta tersebut. Sedangkan harta sebagai objek bisnis, ialah suatu zat yang dapat dijadikan sebagai objek bisnis seperti transaksi, jual beli, sewa, gadai, dan lain sebagainya. (Ramadani, 2018)

Dalam Islam terdapat beberapa cara dalam memperoleh harta. Salah satu konsep tersebut ialah ihrazul mubahat dimana manusia dapat menguasai harta yang ada dimuka bumi ini selama harta tersebut tidak bertuan. Dalam literatur lain hal ini dapat dimaknai sebagai penguasaan harta mubah, karena sejatinya harta yang dikuasi belum memiliki pemilik yang sah.

Namun, apakah jika konsep tersebut relevan apabila di terapkan pada era saat ini khususnya Indonesia. Mengingat di Indonesia memiliki dua sumber hukum yang dipakai yakni hukum positif
(Undang-Undang Dasar 1945) dan hukum normatif. Dalam hukum positif Indonesia Undang-Undang Dasar pasal 33 ayat 3 menyatakan bahwa "Bumi dan air dan kekayaan alam yang terkandung di dalamnya dikuasai oleh negara dan dipergunakan untuk sebesar-besar kemakmuran rakyat".

Dengan adanya Undang-Undang tersebut, jelas dikatakan bahwa segala sesuatu yang terdapat di Indonesia dalam hal ini ialah tanah, air dan kekayaan alam lainnya dikuasai oleh negara. Hal ini menjadi penting dikarenakan sebagai negara dengan penduduk muslim terbesar di Asia menjadikan Indonesia mempertimbangkan hukum normatif dalam hal ini ialah hukum Islam. Sedangkan dalam konsep kepemilikan harta di Islam khususnya ihrazul mubahat dinilai bertolak belakang dengan hukum positif di Indonesia.

Lebih lanjut, pembahasan mengenai konsep kepemilikan harta dalam Islam banyak diangkat seperti peneleitian yang dilakukan oleh T. Sirajuddin mengenai rekonstruksi kepemilikan harat dalam Islam. Namun, dalam penelitiannya tidak dibahas secara mendetail mengenai konsep ihrazul mubahat.

Dengan demikian, berdasarkan paparan tersebut, penulis dalam hal ini bermaksud untuk mengkaji konsep harta dan kepemilikannya dalam Islam khususnya mengenai konsep ihrazul mubahat, serta tanggapan kritis mengenai konsep tersebut dalam aktualisasinya, apakah konsep ihrazul mubahat relevan diterapkan pada konteks dewasa kini? 


\section{METODE PENELITIAN}

Metode yang digunakan adalah deskriptif kualitatif, yang diinterpretasikan menggunakan pendekatan teologis normatif serta argumentasi ilmiah yang bersifat understanding. Teknik analisis yang dilakukan penulis menggunakan metode library research, yakni serangkaian proses dimana penulis melakukan pengumpulan data pustaka, dokumen-dokumen tertulis yang berisikan pemahaman beserta keterangan mengenai persoalan yang sesuai dengan maslah dan tujuan penelitian. Kemudian peulis mencatat dan menafsirkan serta menghubung-hubungkannya dengan argumentasi llmiah untuk dijadikan sebagai hasil analisis.

\section{KONSEP HARTA DALAM ISLAM}

Harta dalam pandangan Imam Hanafiah ialah segala sesuatu yang dapat dimiliki dan dimanfaatkan. Terdapat dua unsur primer dalam pada harta menurut pandangannya.

1. Harta dapat dimiliki, dalam hal ini ialah manusia dapat menguasi atasnya.

2. Harta dapat dimanfaatkan seperti yang berlaku pada daerah tersebut. Pada pandangan imam hanafiah memberkan penerangan harta memiliki manfaat dan dimiliki oleh manusia baik dia mengambil manfaatnya dari barang atau berupa jasa dari barang tersebut.

Sedangkan konsep harta dalam pandangan ushul fiqih merupakan termasuk keperluan pokok bagi kebutuhan manusia, sehingga permasalahan harta dimasukan ke dalam al-daruriyat alkhamsah (lima keperluan pokok) yang terdiri dariagama, jiwa, akal, keturunan dan harta. Selain sebagai sarana untuk kebutuhan pokok manusia, harta juga merupakan perhiasan dunia, sarana untuk mendatangkan kesenangan bagi manusia di dunia.

Dimayuddin Djuwaini mengatakan yang dikutip oleh (Ramadani 2018) bahwa, sesuatu akan dikatakan sebagai almāl jika dapat memenuhi dua kriteria:

1) Dapat memenuhi hajat hidup manusia. Sehingga dapat tercukupi segala kebutuhannya, dan menciptakan ketentraman darinya, baik berifat materi maupun immateri.

2) Sesuatu tersebut harus dapat dimiliki atau dikuasai oleh manusia itu sendiri. Dengan demikian, apabila sesuatu tersebut tidak dapat atau belum di miliki, maka sesuatu tersebut tidak bisa dikatakan sebagai harta (al-mal). (Ramadani, 2018)

\section{PEMBAGIAN HARTA DALAM ISLAM}

\section{Pembagian Harta Berdasarkan Kebolehan Pemanfaatan Menurut Syara'}

Dalam konteks ini harta terkategori dalam dua jenis, yakni al-māl al-mutaqawwim (Harta Bernilai) dan almāl ghair al-mutaqawwim (Harta Tidak bernilai). Harta bernilai maksudnya ialah harta yang dapat dimiliki dan diperbolehkan penggunaannya secara syara'.

Mnurut az-Zuhaily, harta ini merupakan jenis harta yang diapatkan melalui sebuah upaya, dan usaha. (azZuhaily, 2004) Sedangkan harta yang tidak bernilai ialah harta tersebut tidak dapat dikuasai atau dapat dimaknai sebagai sesuatu yang penggunaannya tidak diperbolehkan secara syara' ke- 
cuali dalam kondisi darurat (terpaksa). (NAerul Edwin, 2017)

Dengan adanya pembagian harta menjadi mutaqawwim dan ghair almutaqawwim, maka muncul beberapa impikasi hukum yang perlu diperhatikan di dalamnya:

a. Harta al-mutaqawwim dapat dijadikan sebagai objek transaksi, sehingga dengan tidak adanya objek tersebut maka transaksi dianggap batal. Akan tetapi, harta yang terkategori sebagai ghair al-mutaqawwimialah harta yang tidak bisa dijadikan sebagai objek transaksi. Apabila harta tersebut dipaksakan untuk dijadikan sebagai objek transaksi, maka transaksi tersebut tidak sah hukumnya.

b. Apabila terjadi kerusakan, ataupun kehilangan atas harta tersebut maka adanya suatu keharusan untuk mengganti harta tersebut. Dapat diganti sesuai dengan padanannya atau semisalnya, namun tidak dapat diganti sesuai nilainya (hal ini berlaku untuk harta al-mutaqawwim).

c. Untuk harta yang terkategori sebagai ghair al-mutaqawwim jika terjadi kerusakan atau hilang daripadanya yang dilakukan oleh seorang muslim, makan seseorang tersebut tidak wajib untuk menggantinya.

\section{Pembagian Harta Berdasarkan Sifatnya}

Pembagian berdasarkan sifat harta dibagi menjadi dua, yaitu: harta tidak bergerak ('iqrar) dan harta bergerak (manqul). Harta tidak bergerak adalah harta yang kekal ditempatnya, tidak boleh dipindah, diubah ke tempat yang lain, contoh: tanah dan bangunan permanen. Sedangkan harta bergerak adalah dapat dengan cepat dipindah- kan dan dialihkan, contoh uang, barang perniagaan. (Huda, 2011)

Adapun implikasi hukum atas terbaginya dua harta tersbut ialah sebagai berikut:

a. Dalam harta 'iqrar di dalamnya terdapat syuf'ah, sedangkan dalah harta manqul tidak ada kecuali harta manqul tesebut menjadi bagian tak terpisah dari harta 'iqrar.

b. Harta 'iqrar dapat ditransaksikan meskipun belum adanya serah terima, namun hal ini tidak dapat diterapkan di harta manqul, karena harta manqul memiliki resiko kerusakan yang sangat besar sehingga ketika ditransaksikan maka harus pula diserah terimakan di saat yang sama.

\section{Harta Menurut Pemanfaatannya}

Harta menurut pemanfaatannya dibagi menjadi dua, yaitu; harta alisti'mali yaitu harta yang tidak habis dzatnya apabila telah dipergunakan sekalipun benda itu telah banyak dimanfaatkan. Sedangkan harta alistihlaki adalah harta yang akan habis dzatnya apabila telah dipergunakan. (Mardani, 2013)

Implikasi hukum dari kedua harta tersebut ialah bahwa harta tersebut dapat dijadikan sebagai objek transaksi. Dimana harta tersebut dapat dijadikan sebagai sarana untuk memenuhi kebutuhan konsumsi.

\section{Harta Serupa (al-mithli) dan Harta Senilai (al-qimi)}

Harta serupa dan harta senilai adalah harta ada tidaknya dipasaran. Harta serupa adalah harta yang jenisnya dapat ditimbang, ditakar, contoh; beras, gandum, gula, kapas, besi. Harta 
senilai adalah dimaknai sebagai harta yang limited edition, maksudnya ialah tidak ada objek lain yang dapat menyamai harta tersebut, walaupun ada pasti objek tersebut akan tetap memiliki perbedaan baik dari segi nilai maupun harga. Seperti alat-alat rumah tangga dan logam mulia. (Djuawaini, 2008)

\section{Harta Berdasarkan Kepemilikannya}

Harta berdasarkan kepemilikan dikelompokkan menjadi dua, yaitu; harta milik pribadi dan harta milik masyarakat. Harta milik pribadi adalah harta yang dimiliki oleh perorangan, dimana masng-masing dari pemilik tersebut dapat mendayagunakan harta tersebut sesuai dengan kehendaknya selama hal tersebut tidak merugikan pihak lain. Harta milik publik adalah harta yang pemanfaatannya untuk umum atau semua orang. Contoh; tempat ibadah, jembatan, jalanan, tanah wakaf. (Nasroen, 2007)

\section{Penggunaan Harta dalam Ekonomi Islam}

Dalam Islam, manusia diperintahkan untuk mendayagunakan hartanya tidak hanya untuk kepen-tingan atas dirinya pribadi. Namun, Islam mendorong para pemeluknya untuk senantiasa memanfaatkan harta-nya untuk keperluan sosial dan fi sabilillah, termasuk di dalamnya zakat, infaq, sedeqah, dan wakaf.

Kebutuhan yang harus dipenuhi tidak hanya kebutuhan materi duniawi namun juga ukhrawi. Implikasi dari penggunaan harta tersebut ialah untuk menghidari kemudharatan, dan kemu- dian dapat menciptkan kemaslahatan bagi kehidupan umat manusia.

Islam melarang perolehan harta yang tidak sesuai syari'at. Dalam ekonomi Islam pengembangan harta dilakukan dengan beberapa bentuk pengembangan harta dengan cara syirkah, adalah transaksi dua orang atau lebih, yang kedua belah pihak sepakat untuk melakukan kerja dan bertujuan untuk mendapatkan keutungan.

Syirkah tersebut mengharuskan adanya ijab dan qobul sekaligus. Sedangkan syarat sahnya sangat tergantung dari yang ditransaksikan. Ada beberapa bentuk syirkah ialah sebagai berikut;

syirkah abdan, adalah kerja sama dua orang atau lebih. Dimana, dalam hal ini kedua belah pihak yang bersyirkah sama-sama mengkontribusikan keahliannya tanpa harta dari mereka keuntungan dibagi sesuai dengan kesepakatan mereka. (Antonio, 2001)

syirkah inan, adalah kerja sama yang dilakukan dan masing-masing pihak sama-sama mengkontribusikan harta dan tenaganya dalam melakukan syirkah. Kedua belah pihak tersebut sama-sama mengelolah usaha tersebut, kemudian keuntungannya dibagi sesuai dengan kesepakatan diantara mereka. (Antonio, 2001)

syirkah wujuh, adalah kerja sama yang dilakukan dua belah pihak dalam melakukan syirkah dengan memberkan tenaga sedangkan modal dari orang lain atau pihak di luar dari belah pihak tersebut yang melakukan syirkah. Kemudian keuntungan dibagi ber- 
dasarkan kesepakatan masing-masing pihak. (Antonio, 2001)

syirkah mufawadah, adalah syirkah di antara dua bentuk syirkah sebagai gabungan bentuk semua syirkah yang telah disebutkan sebelumnya. Syirkah ini dapat menggabungkan dua bentuk syirkah, misalnya, syirkah inan dengan syirkah wujuh. (Antonio, 2001)

\section{HARTA SEBAGAI KEPEMILIKAN DAN OBJEK BISNIS}

Harta merupakan hal yang memiliki nilai esensi tinggi dalam kehidupan manusia. Tanpa adanya harta, manusia terhalang bahkan tidak mampu untuk memenuhi kebutahan hidupnya. Proses pemenuhan tersebut dapat dimaknai sebagai aktivitas muamalah. (Ramadani, 2018)

Harta merupakan sarana yang diperlukan untuk mempersiapkan bekal baik di dunia maupun di akhirat. Hal ini sesuai dengan konsep maqashid asy-syariah yang dijadikan sebagai landasan utama dalam mencapai suatu kemaslahatan kehidupan. Disamping itu, al-Qur'an berkali-kali menyerukan untuk membelanjakan/meniagakan sebagian hartanya. (NAerul Edwin, 2017)

Secara fithrah manusia tidak dapat hidup sendiri, melainkan saling membutuhkan satu sama lainnya. oleh karenanya, harta merupakan hal krusial dalam kehidupan sehari-hari yang dimiliki manusia. (Muhit, 2017) Pada dasarnya, harta atau kekayaan ialah milik Allah SWT dimana manusia diberi keleluasaan untuk memberdayakan harta tersebut sesuai dengan kebutuhannya

Muhammad Baqir Ash-Shadr mengungkapkan bahwa sejatinya Allah lah sang maha pemilik atas segala sesuatu di dalam dunia ini. Namun, hal tersebut telah dimandatkan oleh Allah kepada manusia sebagai khalifah di bumi untuk mendayagunakan harta tersebut dengan sebagaimana mestinya.

Dengan demikian dalam konsep ekonomi Islam dikenal dengan beberapa kepemilikan atas harta, seperti kepemilikan harta individu, umum, dan negara. Hal ini dilakukan agar harta tersebut dapat terdistrunusi secara merata, sehingga tidak adanya ketimpanganketimpangan sosial dalam masyarakat.

Sementara Ahmad Fikri yang merujuk pada Taqyuddin al-Nabhani menjelaskan bahwa bdalam Islam juga dijelaskan secara gamlang mengenai kepemilikan individu, publik, maupun negara. Sehingga konsep yang diusung ekonomi Islam tersebut telah menyesuaikan pada syariat Islam yang sebagaimana mestinya. (Fihri, 2017)

Senada dengan hal tersebut Samith Atif al-Zain yang dutip oleh D, Hafifuddin mengemukakan bahwa kepemilikan (property) menurut pandangan Islam dibedakan menjadi tiga kelompok yaitu Kepemilikan Individu, kepemilikan umum dan kepemilikan negara. (Hafifuddin, 2007)

Dalam kontekstualisasi fiqih bisnis Islam, harta dapat dijadikan sebagai objek dalam transaksi jual beli, sewa-menyewa, objek atas kontrak kerjasama atau transaksi ekonoomi lainnya. Disamping itu, jika dilihat dari karakterisktik dasarnya, harta bisa dijadikan sebagai objek kepemilikan kecuali terdapat faktor-faktor yang menghalanginya.

Harta dalam ekonomi Islam saat ini merupakan perihal yang sangat penting. Hal ini sejalan dengan pesatnya per- 
tumbuhan industri syariah, lembaga keuangan dan perbankan syari'ah. Berbicara mengenai harta yang dijadikan sebagai objek bisnis, maka hal ini erat kaitannya dengan konteks transaksi/ akad sebagai salah satu aktivitas yang tidak terlepaskan didalam dunia bisnis.

\section{KONSEP KEPEMILIKAN HARTA}

\section{Kepemilikan Harta Secara Individu}

Kepemilikan harta secara Indvidu (private ownership) dimaknai sebagai kepemilikan harta atas perorangan. Dimana seseorang tersebut memiliki hak sepenuhnya untuk memiliki, menguasai, dan mendayagunakannya. Sehingga, apabila ada orang lain yang ingin memiliki dan menguasai harta tersebut maka, harus seizin dan sepertujuan dari pemilik awalnya. (alSadr, 2008)

Hal ini sesuai dengan ajaran Islam itu sendiri dimana Allah telah mengizinkan manusia untuk mengusai atas dzat-dzat tertentu dan melarangnya atas dzat yang lain. Begitupula hal tersebut berlaku dalam hal transaksi yang dilakukan oleh manusia. (Silistiawati, 2017)

Sebagai contoh, Allah melarang seorang muslim untuk mengkonsumsi minuman keras dan babi, sebagaimana Allah melarang muslim untuk memiliki harta dari hasil riba dan perjudian. Tetapi Allah memberi izin untuk melakukan jual beli, bahkan menghalalkannya, di samping melarang dan mengharamkan riba.

Ajaran Islam membolehkan hak atas kepemilikan harta individu sudah dijelaskan dalam al-Qur'an. Allah memerintahkan manusia untuk bekerja agar memeroleh apa-apa yang diinginkannya dan menjadi hak miliknya. Hal ini termuat dalam QS al-Jumu'ah ayat 10 .

Adapun sebab-sebab kepemilikan harta secara individu apat diperoleh warisan, kompensasi, dan pemberian negara. Beberapa penjelasan mengenai sebab-sebab kepemilikan harta individu di antaranya adalah sebagai berikut: (Harahap, 2015)

Ihrazul Mubahat, ialah kepemilikan harta secara individu atas harta yang bebas. Bebas dalam hal ini dimaknai bahwasanya harta tersebut tidak memiliki tuannya, seperti ikan yang berada di laut, tanah yang tidak produktif, hewan dan pepohon yang ada di hutan tanpa pemilik.

Tawallud, ialah kepemilikan individu atas binatang ternak, termasuk keturunan yang dilahirkan binatang tersebut. Tidak hanya itu, kepemilikan atas hasil perkebunan yang produktif juga dimaknai sebagai kepemilikan individu.

Al-Khalafiyah, kepemilikan individu yang didapatkan dengan cara kepemindahan hak atas kepemilikan suatu objek Seperti harta yang didapat dari waris.

'Aqad, kepemilikan individu yang didapat melalui kesepakatan yang terjadi melalui ijab dan qabul sesuai dengan kentuan syari'ah sehingga menimbulkan pengaruh hukum terhadap objek akad. 


\section{Kepemilikan Harta Umum}

Kepemilikan harta umum adalah harta yang dimiliki, digunakan, dan diambil manfaatnya oleh publik. Dan harta ini tidak boleh dimiliki secara perorangan.

Dalam Islam, keberadaan harta yang menjadi milik publik merupkan suatu aspek krusial. Hal ini dikarenakan bahwa dengan adanya harta bersama maka dapat terbentuknya pemerataan sosial, dalam hal ini semua masyarakat dapat menikmati kegunaan, dan manfaat dari harta tersebut, sehingga dengan adanya hal ini ketimpangan sosial dapat terhindarkan.

Berdasarkan hal itu yang merupakan harta publik ialah segala fasilitas atau objek yang dipandang sebagai sesuatu yang memiliki daya guna tinggi dalam rangka memenuhi hajat hidup masyarakat. Fasilitas umum adalah harta berupa apa saja yang dipandang sebagai kebutuhan bersama.

Abdurahman al-Maliki dalam bukunya menjelaskan bahwa syara' telah membatasi harta benda yang menjadi milik umum, yaitu harta benda yang tidak sah menjadi milik individu karena tiga hal yaitu:

a. Harta yang jumlahnya tidak terbatas.

b. Sumberdaya alam yang sifatnya menghalangi untuk dimiliki oleh personal.

c. Harta benda yang merupakan fasilitas umum, jika tidak ada di dalam suatu negeri, suku atau komunitas maka akan berpotensi sengketa dalam mencarinya.

\section{Kepemilikan Negara}

Kepemilkan harta negara ialah kepemilikan yang dimiliki oleh suatu negara, dimana harta tersebut sudah dtetapkan untuk kepentingan rakyat atau kaumnya.

Hak atas pengelolaan harta ini diserahkan kepada pemimpin sesuai dengan ketentuan syara' dan negara yang berlaku. Dalam masa peradaban Islam. Negara dapat menguasai harta dilakukan dengan beberapacara. Tentu saja cara-cara ini merupakan cara-cara yang disesuaikan dengan syari'at Islam dan mencontoh apa-apa yang telah dilakukan oleh Nabi Muhammad saw sewaktu dahulu.

Dalam Islam adapun harta yang dapat dikuasai oleh negara ialah harta yang diperoleh atas dasar sebagai berikut: (Huda, 2011)

1) Jizyah, ialah harta yang diperoleh negara yang bersumber dari warga non-muslim yang bertempat tinggal di kawasan penguasaan negara muslim, sebagai jaminan perlindungan.

2) Ghanimah, harta yang didapat ketika berperang. Dimana harta tersebut ialah harta yang ditinggal oleh musuh muslim dalam berperang.

3) $F a^{\prime} i$ harta yang diserahkan oleh non muslim tanpa melalui peperangan).

4) Kharaj, kewajiban rakyat untuk mengeluarkan harta yang diperolah dari pengelolaan atas tanah yang dimiliki negara.

5) Usyur, tanah negeri-negeri yang penduduknya memeluk Islam tanpa peperangan.

6) Khumus, seperlima dari rikaz (barang temuan) dan denda sanksi pidana; juga termasuk harta milik negara 
berupa padang pasir, gunung, pantai dan tanah mati yang belum ada pemiliknya, ash-shawafi, marafiq, dan semua bangunan yang didirikan oleh negara dengan menggunakan harta baitul mal.

Namun, seiring berkembangnya zaman terdapat beberapa perubahan mengenai tatacara perolehan harta oleh negara. Hal ini disesuaikan dengan sisitem-sistem kenegaran yang sudah ditur sedemikian rupa guna untuk mewujudkan kesejahteraan sosial.

Negara dalam hal ini dapat dikatakan sebagai pelindung dan pemakmur penduduk yang ada dalam otoritas wilayahnya. Harta dibawah kepemilikan negara merupakan suatu unsur penting dalam kehidupan bernegara. Ini terjadi serta merta hanya untuk mencukupi kebutuhan maupun fasilitas rakyat serta dapat memakmurkan rakyat sehingga dapat tercapainya suatu kemaslahatan dan terhindar dari segala hal mudharat.

Disamping itu, harta yang dimiliki negara dapat digunakan sebagai sumber keuangan pokok, yang dapat dikelola dengan sedemikian rupa sehingga memperoleh keuntungan yang dijadikan sebagai sumber pendapatan negara, yang alokasinya digunakan untuk memakmurkan institusi pengembang negara dan rakyatnya.

Sampai disini telah jelas bahwa ekonomi Islam telah memberikan payung hukum serta batasan-batasan tertentu terhadap umat manusia untuk memiliki harta kekayaan alam baik itu dalam ruang lingkup kepemilikan individu, kempilikan umum maupun kepemilikan negara.
Maka dengan itu fitrah kepemilikan yang terdapat dalam jiwa manusia dapat terealisasi dengan baik, tidak memasung dan memeberikan kungkungan dan batasan yang membawa kearah ketidak kreatifan serta tidak pula memberi kebebasan secara mutlak terhadap individu dalam menguasai dan mengelolah harta kekayaan alam yang dapat mengantarkan ke gerbong eksploitasi.

Tetapi pandangan ekonomi Islam terhadap kepemilikan adalah pandangan yang tawazun, pendngan yang memiliki keseimbangan individu, masyarakat dan negara dalam memiliki harta kekayaan alam. Maka dapat diharapkan bahwa harta kekayaan alam dapat menjadi peranti ekonomi umat dalam meraih kemakmuran, yakni terpenuhinya kebutuhan dharuriyah, hajiyah dan tahsiniyah melalui pemanfaatan harta kekayaan alam dengan adil. (Sirajuddin, 2019)

\section{KONSEP KEPEMILIKAN HARTA IHRAZUL MUBAHAT}

Ihrazul mubahat merupakan salah satu konsep penguasaan harta dalam Islam yang bermkana penguasaan atas harta yang tak bertuan (mubah). (az-Zuhaily, 2004) Seseorang dapat memiliki harta tersebut dikarenakan belum dimiliki oleh siapapun serta tidak adanya pengalang dari syariat untuk memilikinya. Sementara diketahui bahwa sebeb-sebab kepemilikan melalui akad, tawallud, dan khilafiyah merupakan proses cara kepemilikan harta yang sudah bertuan.

Adapun karakteristik harta yang terkategori ihrazul mubahat ialah sebagai berikut (Tanti, 2019): 
a. Harta tersebut belum dimiliki oleh siapapun seperti air di sumbernya, rerumputan liar, pepohonan di hutan liar, binatang buruan baik di darat maupun lautan, dan tanah yang belum terjamah oleh manusia.

b. Harta tersebut dianggap sah dikarenakan suatu akibat dar perbuatan, bukan perkataan. Jadi, semua orang berhak memiliki harta tersebut tanpa syaratsyarat tertentu seperti syarat dalam kepemilikan harta melalui akad.

Dlam rangka menguasai harta harta ihrazul mubahat terdapat dua syarat yang harus dipenuhi: (Djazuli, 2007)

a. Tidak didahului oleh orang lain. Artinya harta tersebut belum dimiiki oleh siapapun, jadi ketika sudah ada orang yang mendahuluinya maka tidak dapat lagi menguasai harta tersebut, karena siapa yang lebih dahulu menguasai maka ia lebih berhak atasnya.

b. Terdapat itikad (niat) untuk memilikinya. Ini sesuai dengan kaidah figh yakni (segala sesuatu tergantung pada niatnya).

Dalam menguasai harta ihrazul mubahat, terdapat empat cara yang dapat dilakukan yakni: (Tanti, 2019)

a. Ihya al-mawat

Mengidupkan tanah yang mati. Dalam hal ini ialah tanah yang tidak ada pemiliknya serta tidak dimanfaatkan pula keberadaannya oleh orang sekitar. Seseorang dapat mengelola sekaligus menguuasai atas tanah tersebut dengan cara menghidupkannya kembali seperti dibuat sumur, ditanami pepohonan atau tumbuh-tumbuhan.

Dengan demikian, dibukanya tanah baru menyebabhkan timbulnya hak milik atas tanah tersebut. Ini sesuai dengan hadits berikut:

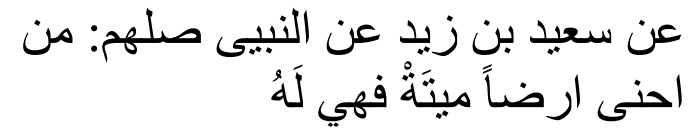

"Dari said bin Zaid, Nabi saw bersabda: Barang siapa menghidupkan tanah yang mati (membuka lahan baru) maka tanah tersebut jadi miliknya" (HR. Abudaud, anNasai dan Tirmidzi).

b. Al-ishtiyad

Menguasai harta dengan cara berburu. Maksudnya ialah menangkap binatang liar baik yang berada di darat, udara maupun laut yang belum dimiliki oleh siapapun. Sehingga dengan cara ini seseorang berhak atas binatang yang didapatnya dengan cara berburu tersebut untuk jadi miliknya.

c. Istila' 'ala al-Kala' wa al-Ajam'

Menguasai rerumputan maupun pepohonan liar hutan. Dalam hal ini ialah rerumputan maupun pohon yang tumbuh sendiri (secara liar) dapat dimanfaatkan secara langsung oleh siapa saja karena hal tersebut berstatus ibahah ashaliyah (sejak awalnya memang diperbolehkan), ini sesuai dengan hadits berikut:

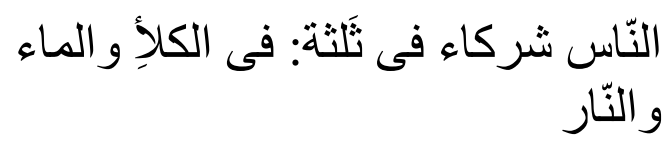

"Manusia berserikat pada tiga hal yaitu: rumput, air, dan api" (HR. Ahmad dan Abu Daud).

d. Menguasai barang tambang, dalam hal ini ialah emas, perak, tembaga, besi, alumunium, batu bara dan sebagainya. Maksudnya ialah jenis harta tersebut dapat dimiliki apabila harta tersebut mengikut pada tanah yang dimiliki atas seseorang tersebut. 


\section{KRITIK TERHADAP KONSEP HARTA DAN KEPEMILIKAN DALAM ISLAM}

Manusia tidak dapat terlepas dengan harta dalam menjalani kehidupan sehariharinya. Maka dari itu, harta merupakan suatu aspek terpenting dalam kehidupan manusia untuk memenuhi segala kebutuhannya.

Terdapat tiga kategori kepemilikan harta dalam Islam yaitu: kepemilikan harta individu, kepemilikan harta umum, dan kepemilikan harta oleh negara.

Walaupun dalam Islam menyatakan bahwa sejatinya hanya Allah SWT yang berhak atas harta yang ada dimuka bumi. Namun, Allah mengutus manusi sebagai khalifah untuk mengelola kekayaan dimuka bumi guna menciptakan kemaslahatan di dalamnya. Dengan demikian dalam Islam juga mengakui adanya kepemilikan harta individu. Hal ini sesuai dengan yang dipaparkan oleh Sulistiawati (Silistiawati, 2017) dalam Konsep Kepemilikan Harta dalam Islam yang menyatakan bahwa dibolehkannya kepemilikan harta indivdu ialah agar manusi mau bekerja untuk memenuhi kebutuhan hidupnya, dimana ini juga sesuai dengan kaidah maqasid asy-syariah yakni hifdz al-nafs (mejaga jiwa) agar dapat memberikan kemaslahatan bagi dirinya untuk didunia maupun di akhirat. (Auda, 2008)

Salah satu cara kepemilkan harta dalam Islam ialah Ihrazul Mubahat yang dimaknai sebagai kepemilikan atas harta bebas (harta yang belum ada penguasanya) dicontohkan seperti:

1. Tanah gambut tidak produktif yang tidak ada pemiliknya;

2. Pepohonan dan tanah yang ada dihutan tanpa pemilik;
3. Ikan yang ada di laut, dan lain sebagainya.

Kepemilikan harta Ihrazul Mubahat dalam konsep Islam sah-sah saja karena mengaggap bahwa objek harta yang dicontohkan tersebut berhak untuk dimilki. Hal ini merujuk pada konsep dimana pada hakikatnya harta/kekayaan alam ialah milik Allah SWT, dan manusia sebagai khalifah di bumi yang dianjurkan serta ditugaskan untuk memanfaatkan harta/kekayaan alam.

Namun demikian, apakah konsep tersebut sudah relvan apabila diterapkan pada era saat ini khususnya di Indonesia yang meganut dua sumber hukum yakni hukum positif dan hukum normatif.

Penelitian yang dilakukan oleh Tjek Tanti yakni Cara Halal Memiliki Harta (Tanti, 2019) menyebutkan bahwasanya harta ihrazul mubahat merupakan harta mubah dimana harta tersebut belum dimiliki oleh siapapun seperti: tanah kosong yang tidak ada pemiliknya, bintang liar yang ada di darat, udara maupun air, rerumputan dan pepohonan liar di hutan, serta hewan liar hasil buruan.

Hal-hal di atas tersebut disebutkan dapat dikuasai atau dimiliki oleh seseorang selama belum ada pemiliknya. Diperkuat dengan hadits yang diriwayatkan oleh Imam Abu Daud, an-Nasai dan Tirmidzi yang menjelaskan bahwa Nabi SAW memperbolehkan hak atas kepemilikan tanah kososong yang tidak bertuan apabila seseorang tersebut telah menghidupkannya kembali (membuka lahan kosong untuk diproduktifkan). (alKhalani, 1980)

Mengkritisi hal tersebut, diketahui bahwa di Indonesia terdapat Undang- 
Undang Dasar yang dijadikan sebagai sumber hukum dimana dalam UndangUndang tersebut mengatur menganai kepemilikan harta individu, umum maupun negara. Seperti Undang-Undang Pasal 33 ayat 3 yang berbunyi: "Bumi dan air dan kekayaan alam yang terkandung di dalamnya dikuasai oleh negara dan dipergunakan untuk sebesar-besar kemakmuran rakyat". Kemudian disusul dengan Undang-Undang pasal 33 ayat 2 yang berbunyi: "Cabang-cabang produksi yang penting bagi negara dan yang menguasai hajat hidup orang banyak dikuasai oleh negara".

Hal ini menunjukkan bahwa kekayaan yang ada di bumi Indnesia merupakan hak Negara, yang artinya seseorang tidak bisa sembarangan mengklaim atas kepemilikikan harta atau kekayaan yang belum dimiliki oleh siapapun, karena terdapat hak negara didalamnya.

Berdasarkan hal tersebut, penulis berasumsi dengan berlandaskan pemaparan diatas bahwa konsep ihrazul mubahat dinilai belum relevan apabila diterapkan pada era saat ini. Hal ini karena akan berbenturan dengan konsep kepemilikan harta oleh negara yakni dengan adanya Undang-Undang Pasal 33 ayat 2 dan 3 . Serta berbenturan dengan konspe kepemilikan harta secara umum karena dalam konsep kepemilikan harta secara umum (publik) terdapat adanya hak ulayat, dimana makna dari hak ulayat itu sendiri ialah hak penguasaan atas tanah (harta) oleh masyarakat hukum adat atau serangkaian wewenang dan kewajiban atas suatu tanah (harta) yang berda dilingkungan wilayahnya. Ini sesuai dengan Undang-Undang No. 5 Tahun 1960.
Dengan demikian, perlu adanya regulasi secara figh untuk mengatur sedemikian rupa mengenai pembatasan dalam penguasaan dan penggunaan harta dalam konteks ihrazul mubahat khususya di Indonesia.

\section{KESIMPULAN}

Dalam Islam terdapat tiga jenis kepemilikan atas harta secara individu, umum (publik) dan negara. Kepemilikan harta secara individu dapat diraih melalui empat cara yakni Ihrazul Mubahat, Tawallud, al-Khalafiah, dan akad.

Namun, masih terdapat ketidak jelasan mengenai konsep kepemilikan individu secara ihrazul mubahah, dimana penulis menilai bahwa konsep tersebut masih belum erelevan apabila dikontekstualisasikan pada era saat ini, khususnya di Indonesia.

Hal ini karena akan berbenturan dengan hak-hak kepemilikan atas publik dan negara. Sehingga perlu adanya regulasi secara hukum Islam yang mengatur mengenai batasan-batasan kepemilikan harta yang didapat melalui ihrazul mubahat khususnya di Indonesia.

\section{DAFTAR PUSTAKA}

al-Khalani, M. B. (1980). Subul as-Salam Juz III. Kiaro: Mustafa al-Bab al-Hubb.

al-Sadr, M. B. (2008). Buku Induk Ekonomi ISlam Iqtishaduna. Jakarta: Zahra.

Antonio, M. S. (2001). Bank Syariah dari Teori ke Praktik. Jakarta: Gema Insani.

Auda, J. (2008). Maqashid al-Syariah As The Philosophy of Islamic Law (A System Approach). London: The International Institute of Islamic Thought. 
az-Zuhaily, W. (2004). al-Figh al-Islamy wa Adillatuh, Jilid 4. Jakarta: Gema Insani.

Djazuli, A. (2007). Kaidah FIkih. Jakarta: Kencana.

Djuawaini, D. (2008). Pengantar Figh Muamalah. Yogyakarta: Pustaka Pelajar.

Fihri, A. (2017). Harta dalam Pemanfaatan Filantropi Islam. Jurnal al-Urban 1(2).

Hafifuddin, D. (2007). Agar Harta Berkah dan Bertambah. Jakarta: Gema Insani.

Harahap, I. (2015). Hadits-hadits Ekonomi Cet 1. Jakarta: Kencana.

Huda, Q. (2011). FIgh Muamalah. Yogyakarta: Teras.

Mardani. (2013). Fiqh Ekonomi Syariah: Figh Muamalah. Jakarta: Kencana.

Muhit, M. (2017). Konsep Harta dalam Perspektif Huku Islam. Jakarta: Ikatan Ahli Ekonomi Islam Indonesia.

NAerul Edwin, K. A. (2017). Kosnsep Harta dalam Tinjauan Maqashid Syariah. Jurnal La Riba 3(1).
Nasroen, H. (2007). Figh Muamalah. Jakarta: Gaya Media Pratama.

Ramadani, L. A. (2018). Implementasi Harta dalam Akad (Harta Sebagai Hak Milik Juga Sebagai Onjek Bisnis). Jurnal Iqtishaduna (10) 2.

Samsul. (2019). Analisis Pemanfaatan Harta dalam Konsumsi Masyarakat dalam Ekonomi Konvensional dan Ekonomi Islam. Al-Azhar Journal of Islamic Economics.

Silistiawati, A. F. (2017). Konsep Kepemilikan Harta dalam Islam. Jurnal Syariah (5) 2.

Sirajuddin, T. (2019). Rekonstruksi Konseptual Kepemilikan Harta Harta Perspektif Ekonomi Islam. Jurnal Laa Maysir (6) 2.

Suhendi, H. (2013). Figh Muamalah. Jakarta: Rajawali Press.

Tanti, T. (2019). Cara Halal Memiliki Harta. Taqnin: Jurnal Syariah dan Hukum,1(2) 